\title{
РЕЗУЛЬТАТЫ ВЫЯВЛЕНИЯ ГЕСТАЦИОННОГО САХАРНОГО ДИАБЕТА
}

\author{
1,2 Загарских Е.Ю., ${ }^{3}$ Лабыгина А.В., ${ }^{3}$ Курашова Н.А.
}

'Федеральное государственное бюджетное учреждение высшего образования «Северо-Западный государственный медицинский университет им. И.И. Мечникова» Минздрава России, г. Санкт-Петербург

${ }^{2}$ СПб ГБУз ЛОКБ Перинатальный ченр, Санкт-Петербург

${ }^{3}$ Федеральное государственное бюджетное учреждение «Научный центр проблем здоровья семьи и репродукции человека», г. Иркутск

Гестационный сахарный диабет (ГСД) - заболевание, характеризующееся гипергликемией, впервые выявленной во время беременности, но не соответствующей критериям «манифестного» СД. Распространенность ГСД постепенно растет и составляет от $1 \%$ до 25\% и отражает рост ожирения и сахарного диабета 2 типа во всем мире.

Частота развития осложнений беременности и заболеваемость новорожденных при ГСД колеблется от 2-4\% до 80\%, так многоводие осложняет течение беременности при ГСД в 20-60\% случаев в связи с полиурией плода, реакцией водной оболочки плода в ответ на повышенное содержание глюкозы в околоплодных водах, умеренная преэклампсия развивается в 25-65\% случаев, а тяжелая преэклампсия - в 2,9-3,7\%, диабетическая фетопатия - в 49-60\%. В раннем неонатальном периоде у 5\% детей происходит развитие респираторного дистресс-синдрома в результате ингибирующего воздействия гиперинсулинемии на созревание легочного сурфактанта и угнетение синтеза лецитина, развитие неонатальной гипогликемии. Угроза прерывания беременности и преждевременных родов встречается у 30-50\% пациенток, причем установлена связь между невынашиванием беременности и материнской гипергликемией. Перинатальная смертность при этой патологии в целом в 5 раз выше, чем в популяции, связана с прогрессирующей перинатальной гипоксией и родовой травмой. Поздняя диагностика ГСД связана с тем, что нет явной клиники, в связи с чем необходим активный скрининг на выявление ГСД.

В целом факторы риска возникновения ГСД сходны с факторами, ассоциированными с развитием сахарного диабета 2 типа, и включают возраст матери, ожирение, этническое происхождение, генетическую предрасположенность, случаи выявления ГСД при предыдущих беременностях, крупный вес детей при рождении при предыдущих беременностях, неблагоприятный исход предыдущей беременности, гликозурия, многоводие или макросомия плода по данным ультразвукового скрининга при настоящей беременности.

ЦЕЛЬ: установить частоту ГСД по обращаемости в перинатальный центр, эффективность терапии.

МАТЕРИАЛЫ И МЕТОДЫ: всего за 2019 год акушером-гинекологом было направлено на консультацию эндокринолога 1222 обращений беременных, из них с подозрением на ГСД 555 обращений беременных.

PЕзУЛЬТАТЫ: Диагноз ГСД установлен у 555 обращений беременных (45,4\%): (у 274 (22,5\%) амбулаторных и 280 - (22,91\%) стационарных). Лечебная диета применялась у большинства беременных женщин с ГСД (83\%). Однако у 85 женщин с ГСД использовали инсулинотерапию (15,3\%), поскольку диетотерапия не приводила к нормализации углеводного обмена.

ВЫВОДЫ: при ранней диагностики и коррекции нарушений углеводного обмена у беременных женщин снижается риск развития осложнений как у женщины, так и у ребенка. более чем у $50 \%$ женщин с ГСД в течение последующих 10-15 лет манифестирует СД 2 типа. ГСД является природным стресс-тестом, прогнозирующим отдаленные метаболические и сердечно-сосудистые проблемы у пациентки и ее потомства. Пациенткам, перенесшим ГСД, рекомендуется изменить образ жизни, соблюдать диету, направленную на снижение массы тела, а также расширить объем двигательной активности. Следующую беременность необходимо планировать.

КЛЮЧЕВЫЕ СЛОВА: беременность, преэклампсия, сахарный диабет, инсулинорезистентность. 